\title{
Isolation, Optimization and Molecular Characterization of Novel Lipase Producing Lysinibacillus macroides FS1 from Oil Rich Sample for Biodiesel Production.
}

\author{
Shilpa K Jigajinni ${ }^{1}$ and Dr.Bharati S Meti ${ }^{1}$ \\ 'Department of Biotechnology, Basaveshwar Engineering College (Autonomous), S Nijalingappa Vidyanagar, Bagalkot 587103, Karnataka.
}

Corresponding author: skjbt@becbgk.edu 8722485018

\begin{abstract}
Lipase is one of the promising biocatalyst in field of Enzymatic Biodiesel production. Screening of lipase producing bacteria and its media optimization facilitates enhanced lipase production. Considering the advantages of enzymatic biodiesel production using lipases the objective of present work was to isolate lipase producing bacteria and its media optimization. Bacterial strain were isolated from oil rich sample showing maximum zone of hydrolysis on TBA Media was selected and identified as Lysinibacillus macroides FS1 by $16 \mathrm{SrDNA}$ gene sequence analysis. Lipase production was carried out in production media and lipase activity of $3.1 \mathrm{U} /$ $\mathrm{ml}$ was assayed by titrimetric method. Various media parameters were optimized and maximal lipase activity of $16.75 \mathrm{U} / \mathrm{ml}$ were observed at $48 \mathrm{hr}$ of incubation in optimized media with Honge oil as inducer, Galactose as carbon source , Ammonium Chloride and Beef extract as source of nitrogen, $\mathrm{pH} 7$ and $37^{\circ} \mathrm{C}$ temperature with agitation speed of $120 \mathrm{rpm}$. Under optimized condition 5.4 fold increases in the lipase activity than innate activity was observed. $50.74 \%$ yield was observed with specific activity of $21.25 \mathrm{U} / \mathrm{mg}$ after purification with $30 \%$ ammonium sulphate. Purified lipase was stable in presence of methanol at $37^{\circ} \mathrm{C}$. Results obtained shows that Lipase from Lysinibacillus macroides FS1 was promising biocatalyst for Biodiesel production.
\end{abstract}

Keywords Isolation, Lysinibacillus macroides FS1, Lipase, Optimization, Biodiesel.

\section{Introduction}

Lipases (Triacylglycerol acyl hydrolases, E.C. 3.1.1.3) are group of hydrolases which catalyses the hydrolysis of triacylglycerol to release fatty acids and glycerol. Besides the hydrolytic reactions, lipases are able to catalyze many reactions like transesterification, interesterification, esterification, acidolysis, aminolysis, alcoholysis by using wide-range of substrates with high specificity $(1,2)$. Lipase is believed to be very versatile biocatalyst and potential enzyme for the biotechnology industries becoming a target of several researches. Lipases are used in many different industrial applications, such as household detergent additive, textile industry, cosmetic industry, paper industry, pharma industry, synthesis of biopolymers and biodiesel, agrochemicals, flavor compounds and pharmaceutical compound synthesis etc $(3,4)$. The study of the enzymatic synthesis of biodiesel was encouraged due to increasing pollution and by product separation problems of the chemical catalyzed process. (5).

More research focus is required to isolate industrial important lipase producing microorganisms from different habitats. Lipases are widely employed group of biocatalyst in different biological processes because of their broad substrate specificity and stereo selectivity in reaction (6).Lipases are produced from different species of plants, animals and microorganisms and they exist in different environments like compost heaps, decaying food, dairies, industrial wastes, oil-processing factories, oil seeds, soil contaminated with oil, waste water and petrol spilled soil $(7,8)$. The oil rich environment with organic substrates may furnish a suitable habitat for isolation of lipase producing bacteria (9). Lipase producers can be distinguished by showing a clear halo zone, turbid zone or white crystals around colonies of microbes on specific media such as Tributyrin agar(TBA), Phenol red agar, Tween20/80,Rhodamine B agar plates containing lipidic compounds like triolein, tributyrin, olive oil, tween 20, tween 80 etc. Microbial lipases occupied more industrial applications than plants and animal sources because of its hydrolytic and synthetic activities, high yield, ease in genetic manipulation, regular supply and easy cultivation of microbes on inexpensive media (10). Among microbial lipases bacterial lipases are more economical and stable (3). Most of the Bacterial species secretes lipase extracellular which are majorly affected by nutritional and physicochemical factors such as temperature, $\mathrm{pH}$, nitrogen source and carbon source, inorganic salts, agitation and DO concentration $(11,12,13,14)$.Media containing lipidic carbon, like edible and non-edible oils, fatty acids, glycerol or tweens in the presence of an organic nitrogen source facilitates the lipase production(15). Among many species some of them are efficient extracellular lipase producers mainly Achromobacter, Alcaligenes, Arthrobacter, Pseudomonas, Staphylococcus, Chromobacterium, Bacillus and Pseudomonas spp. (7). Few analyses have been shown the abilities of Lysinibacillus genera with several enzymatic activities including lipolytic, proteolytic, cellulolytic, pectinolytic and amylolytic activities (16). Solvent stable lipases are one of the promising biocatalysts in non-aqueous biological transformations hence focus need to isolate 
the solvent stable lipase producing bacteria's (17). The production of enzymes at industrial scale primarily uses the submerged fermentation technology (SmF), as this method of fermentation process easy to supervise and control (18).

Lipase production from microbial sources and especially from bacteria has interesting topic of study to isolate the lipases with novel and specific properties like catalyzing transesterification of honge oil with lower production and processing cost so that large scale production of biodiesel using lipase becomes more ecofriendly and economically viable. Therefore the present study aims, at isolating and characterizing lipase producing bacteria from oil rich soil samples for biodiesel production.

\section{Material and Methods}

\section{Collection of soil samples}

Soil samples were collected from oil rich samples of different locations like oil processing unit, temple soil and biodiesel production unit (BEC STEP) of Bagalkot region, Karnataka.

\section{Isolation and screening of lipase producing bacteria}

Soil samples were serially diluted upto $10^{-5}$ in sterile distilled water, $1 \mathrm{ml}$ of $10^{-5}$ dilution inoculated on Nutrient agar plate by spread plate technique and incubated for $24 \mathrm{hr}$ of incubation to get isolated colonies. Isolated bacterial strains were screened qualitatively for lipolytic activity by inoculating on Tribyturin agar media (TBA). TBA media was prepared by adding $0.5 \mathrm{~g}$ peptone, $0.3 \mathrm{~g}$ yeast extract, $1 \mathrm{~g}$ tributyrin and $2 \mathrm{~g}$ agar in $99 \mathrm{ml}$ of distilled water and $\mathrm{pH}$ was adjusted to 7 , sterilised at 121 ${ }^{\circ} \mathrm{C}$ for $15 \mathrm{~min}$.Isolated colonies from nutrient agar plate were selected and inoculated on sterilised TBA media and incubated at $37^{\circ} \mathrm{C}$ for $24 \mathrm{hr}$. After $24 \mathrm{hr}$ of incubation zone of clearance were observed due to hydrolysis of tributyrin by lipase. The isolate (FS1) showing the maximum diameter of clear zone was opted for further studies. The isolates were subcultured routinely in the minimal media composed of $0.3 \%$ of yeast extract $0.5 \%$ $\mathrm{NaCl}, 0.5 \%$ peptone, $2 \%$ agar at $\mathrm{pH} 7$ and preserved in agar slants at $4{ }^{\circ} \mathrm{C}$ in the refrigerator.(3).

\section{Identification of lipase producing bacteria by 16SrDNA sequencing.}

The screened positive strain FS1 isolated from hanuman temple soil, vidyagiri ,bagalkot, karnataka found to produce maximum zone of hydrolysis (Table 2) around the colony was studied based on 16S rDNA gene sequencing, BLAST search analysis and phylogenetic tree construction.

\section{Lipase Production by submerged fermentation}

The preinoculum was prepared by inoculating the isolated strain in $10 \mathrm{ml}$ of the production media, incubated at $37^{\circ} \mathrm{C}$ for $24 \mathrm{hr}$. $1 \mathrm{ml}$ of preinoculum were inoculated in the $100 \mathrm{ml}$ of production media in $250 \mathrm{ml}$ conical flask containing $3 \mathrm{~g}$ yeast extract, $3 \mathrm{~g}$ sucrose, $0.01 \mathrm{~g} \mathrm{CaSO}_{4}, 0.05 \mathrm{~g} \mathrm{KH}_{2} \mathrm{PO}_{4}, 0.01 \mathrm{gMgSO}_{4} .7 \mathrm{H}_{2} \mathrm{O}, 1 \mathrm{~g}$ olive oil, $\mathrm{pH}$ set to 7 , incubated at $37^{\circ} \mathrm{C}$ for $24-48 \mathrm{hr}$ in shaking incubator with agitation speed of $120 \mathrm{rpm}$. Sample were collected at respective intervals and centrifuged at $10000 \mathrm{rpm}$ for $30 \mathrm{~min}$ at $4^{\circ} \mathrm{C}$, supernatant were collected as crude enzyme source used for lipase assay $(8,19)$.

\section{Lipase Assay}

The quantitative analysis of lipase was done by titrimetric method using olive oil as substrate. The reaction mixture containing $1 \mathrm{ml}$ of culture supernatant, $2 \mathrm{ml}$ of phosphate buffer with $\mathrm{pH} 7.0$ and $1 \mathrm{ml}$ of olive oil incubated at $37^{\circ} \mathrm{C}$ for $60 \mathrm{~min}$. The reaction was stopped by adding $1 \mathrm{ml}$ of acetone:ethanol solution in $(1: 1)$ ratio and titrated with $\mathrm{NaOH}(0.05 \mathrm{M})$ in presence of phenolphthalein as a indicator until pH 10.5. Amount of $\mathrm{NaOH}$ consumed indicates the amount of fatty acids liberated. One unit of enzyme activity is defined as the amount of enzyme required to liberate $1 \mu \mathrm{mol}$ of equivalent fatty acids (20). Lipase Activity $(\mathrm{U} / \mathrm{ml})=\frac{\text { Vol. of alkali consumed x Strength of alkali x } 1000}{\text { Vol. of sample x Time in min }}$

\section{Optimization of media parameters for maximum lipase production}

a) Incubation Time: The effect of incubation time on lipase production was performed by inoculating the isolate FS1 in production media and incubated at $37^{\circ} \mathrm{C}$ in shaking incubator at a rotary speed of $120 \mathrm{rpm}$ for 96 hours. At every $24 \mathrm{hr}$ of interval crude broth was harvested, aseptically and centrifuged at $10,000 \mathrm{~g}$ for $30 \mathrm{~min}$ at $4{ }^{\circ} \mathrm{C}$. The supernatant collected was used as crude enzyme solution and assayed for lipase activity.

b) Effect of $\mathrm{pH}$ : Effect of $\mathrm{pH}$ on lipase production was studied by varying the $\mathrm{pH}$ of production media from $5,6,7,8,9$ and 10 .

c) Inducer oil: Effect of different Inducer oil on lipase production was analysed by replacing the olive oil $(1 \% \mathrm{w} / \mathrm{v})$ in production media with different oils like Palm oil, Honge oil and Neem oil with the respective final concentration of $1 \%(\mathrm{w} / \mathrm{v})$.

d)Nitrogen source: Effect of different organic and inorganic nitrogen sources formaximum lipase production was studied by replacing yeast extract $(3 \% \mathrm{w} / \mathrm{v})$ present in the production media with different nitrogen sources like peptone, beef extract,tryptone, $\mathrm{NaNO}_{3}$, ammonium sulphate, ammonium chloride and urea with the respective final concentration of $3 \%(w / v)$.

e) Carbon source: To evaluate the effect of different carbon sources on lipase production was analysed by replacing sucrose $(3 \% \mathrm{w} / \mathrm{v})$ present in the production media with different carbon sources like glucose, fructose, maltose, galactose, mannose, starch and 
lactose with the respective final concentration of $3 \%$ $(w / v)$.

All the optimization experiments were performed as one factor at time in triplicates under production conditions like incubation at $37{ }^{\circ} \mathrm{C}$ in orbital shaker at a rotary speed of $120 \mathrm{rpm}$ for $48 \mathrm{hr}$ and lipase activity was assayed.The production of lipase was also observed in optimized media (3gm beef extract,3gm galactose, $3 \mathrm{gm}$ ammonium chloride,0.01gm $\mathrm{CaSO}_{4}, 0.05 \mathrm{gm}$ $\mathrm{KH}_{2} \mathrm{PO}_{4}, 0.01 \mathrm{gm} \mathrm{MgSO}{ }_{4} .7 \mathrm{H}_{2} \mathrm{O}, 1 \mathrm{gm}$ honge oil in $100 \mathrm{ml}$ distilled water and $\mathrm{pH}$ set to 7 ) and lipase activity were compared with innate activity.

\section{Partial purification of lipase}

The lipase produced from Lysinibacillus macroides FS1 in optimized media were partially purified using ammonium sulphlate fractionation (0-30\%). The lipase was precipitated by adding gradually $3 \mathrm{gm}$ of solid ammonium sulphate in $100 \mathrm{ml}$ of culture supernatant with constant stirring at $4{ }^{\circ} \mathrm{C}$. After complete dissolution of ammonium sulphate the flask were kept standing for $30 \mathrm{~min}$ at $4^{\circ} \mathrm{C}$. The pellet were collected by centrifugation at $10000 \mathrm{rpm}$ for $30 \mathrm{~min}$ at $4{ }^{\circ} \mathrm{C}$ and re-suspended in $0.05 \mathrm{M}$ phosphate buffer of $\mathrm{pH} 7$ and tested for enzyme activity(7).

\section{Characterization of lipase}

\section{Protein Estimation by Lowry's Method}

Quantitative estimation of protein content was done by Lowry's method using BSA as standard.

\section{Effect of organic solvents and temperature on lipase activity}

Stability to organic solvent is desirable feature in the process of esterification and transesterification, as these organic solvents may inhibit the lipase activity during tranesterification reaction. Biodiesel production can be greatly enhanced by evaluating stability of lipase to organic solvents. Hence to investigate stability of produced lipase to organic solvents, partially purified lipase was incubated with $1 \mathrm{ml}$ methanol and ethanol for 1 hour as methanol and ethanol are the most commonly used organic solvents in biodiesel industry and residual lipase activity was assayed. Stability and activity of lipase to different temperatures were tested by incubating purified lipase at different temperatures like $25^{\circ} \mathrm{C}, 37^{\circ} \mathrm{C}$ and $45^{\circ} \mathrm{C}$ followed by lipase assay(49).

\section{Results}

Advantages of enzymatic transesterification encourages on the isolation and identification of new strains of lipolytic microorganisms to produce lipase with desired characteristics that could catalyse transesterification reaction so that biodiesel production becomes ecofriendly and cost effective. Considering the advantages of enzymatic tranesterification using lipases, the present study, aspired to isolate, optimize and characterize lipase-producing bacteria from oil rich sample for biodiesel production.

Table 1 : Soil Samples Collected From Different Locations.

\begin{tabular}{|l|l|l|}
\hline SI. No. & $\begin{array}{l}\text { Sample } \\
\text { Code }\end{array}$ & Sample Locations \\
\hline 1 & S1 & Temple Soil, Vidyagiri, Bagalkot \\
\hline 2 & S2 & Oil refinery, Vidyagiri, Bagalkot \\
\hline 3 & S3 & Biodiesel Production Unit,BEC STEP, Bagalkot \\
\hline 4 & S4 & Restaurant Area, Vidyagiri, Bagalkot \\
\hline 5 & S5 & Honge Cake, BEC STEP, Bagalkot \\
\hline 6 & S6 & Neem Cake, BEC STEP, Bagalkot \\
\hline
\end{tabular}

\section{Isolation and screening of lipase producing bacteria}

In the present study six different lipase producing bacteria were isolated from different oil rich samples on TBA media. Lipolytic activity was further screened and characterized by the formation of clear zone of hydrolysis around the colonies indicates extracellular lipase production by the organism. The isolated six bacterial strains were designated as FS1,FS2, FS3,FS4,FS5 and FS6. Among the six bacterial strains one bacterial strain named as FS1 shows maximum zone of clearance on TBA media as shown in Figure 1, were identified as potent lipase producer compared to other isolates as per Table 2.

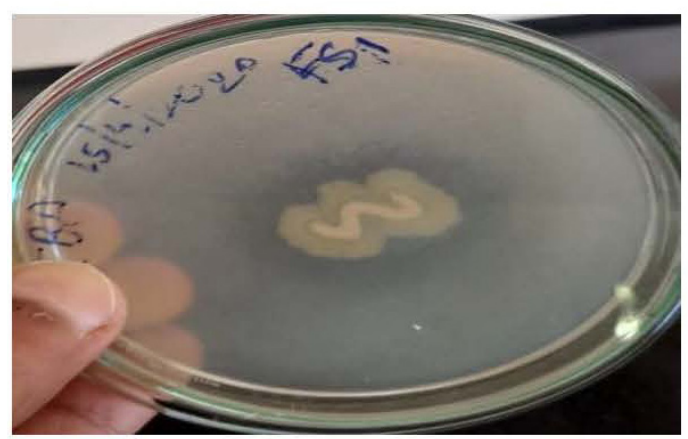

Figure 1: Lysinibacillus macroides FSI showing zone of clearance on TBA media.

Table 2 : zone of Hydrolysis by Different Isolates.

\begin{tabular}{|l|l|l|}
\hline SI.No. & Isolate Code & Zone Size in mm \\
\hline 1 & FS1 & 5 \\
\hline 2 & FS2 & $\begin{array}{l}\text { No } \\
\text { formation }\end{array}$ \\
\hline 3 & FS3 & 2 \\
\hline 4 & FS4 & 1 \\
\hline 5 & FS5 & 2 \\
\hline 6 & FS6 & 1 \\
\hline
\end{tabular}

\section{Identification of lipase producing bacteria}

The selected strain FS1 was identified as Lysinibacillus macroides basesd on 16SrDNA analysis, revealed that FS1 was $98.46 \%$ similarity with Lysinibacillus macroides (NR_114920.I) based on nucleotide homology and phylogenetic analysis(Figure 2). 


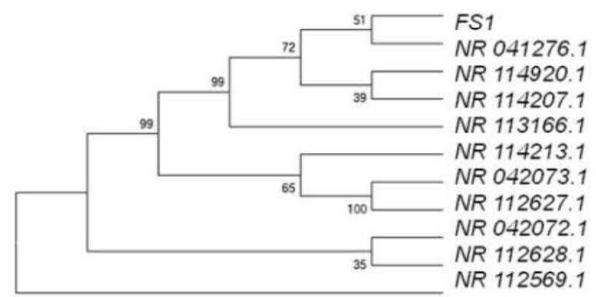

Figure 2: Molecular Phylogenetic Tree Analysis by Maximum Likelihood Method

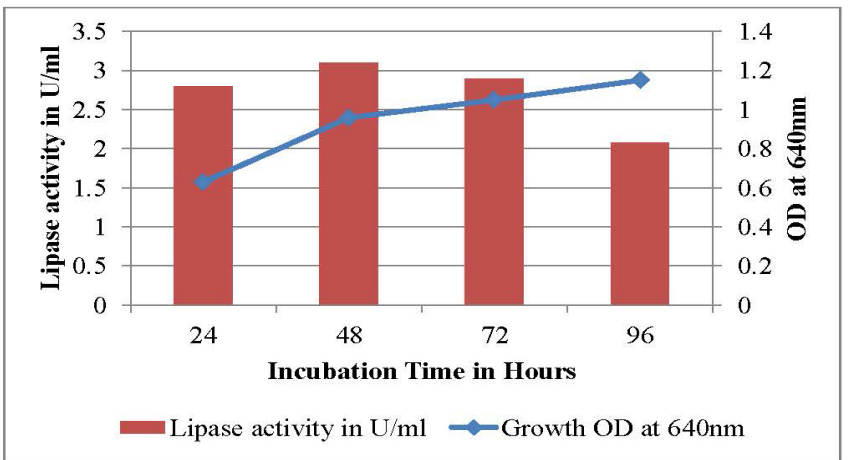

Figure 3: Effect of Incubation Time

Lipase Production by submerged fermentation (SmF)

Lipase production was carried out in production media by submerged fermentation to determine the trends of growth and lipase production. The collected crude lipase sample was assayed for its activity by titrimetric method and it was found that lipase activity of Lysinibacillus macroides FS1 was $3.1 \mathrm{U} / \mathrm{ml}$ at $48 \mathrm{hr}$ of incubation at $37^{\circ} \mathrm{C}$.

\section{Optimization of media parameters}

\section{Effect of Incubation time}

It was observed that the lipase production from the Lysinibacillus macroides FS1 was found maximum $(3.1 \mathrm{U} / \mathrm{ml})$ at $48 \mathrm{hr}$ of incubation. As shown in Figure 3 the production was gradually decreased after $48 \mathrm{hr}$, optical density values of growth bring out that $O D$ was higher at $96 \mathrm{hr}$ but lipase production was maximum at $48 \mathrm{hr}$. The increase in OD may be due to increase in turbidity because of byproducts released during decline phase. This intimates that the lipase production by Lysinibacillus macroides FS1 was occurred in a growth dependent fashion.

\section{Effect of Inducer oil}

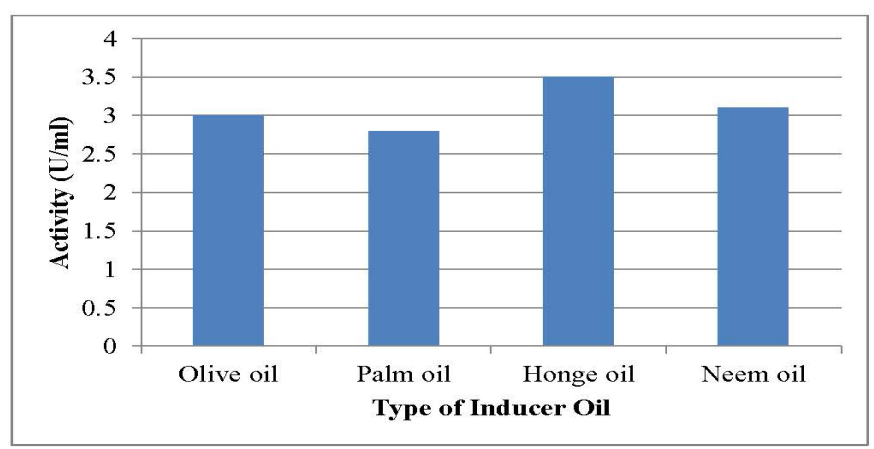

Figure 4: Effect of Inducer Oil on Lipase Activity
It was observed from Figure 4 that highest lipase secretion was noted in presence of honge oil as compared to other oils. Hence honge oil was good inducer for lipase secretion by Lysinibacillus macroides FS1.

\section{Effect of carbon source}

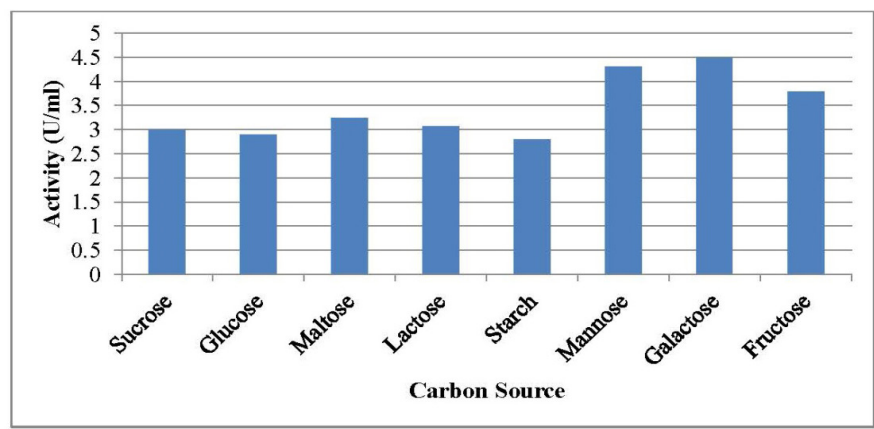

Figure 5: Effect of Different Carbon Sources on Lipase Activity

It was revealed from Figure 5 that Galactose was responsible for enhanced production of lipase in production media as compared to other carbon sources. Hence Galactose will be suitable carbon source for Lysinibacillus macroides FS1.

\section{Effect of Nitrogen source}

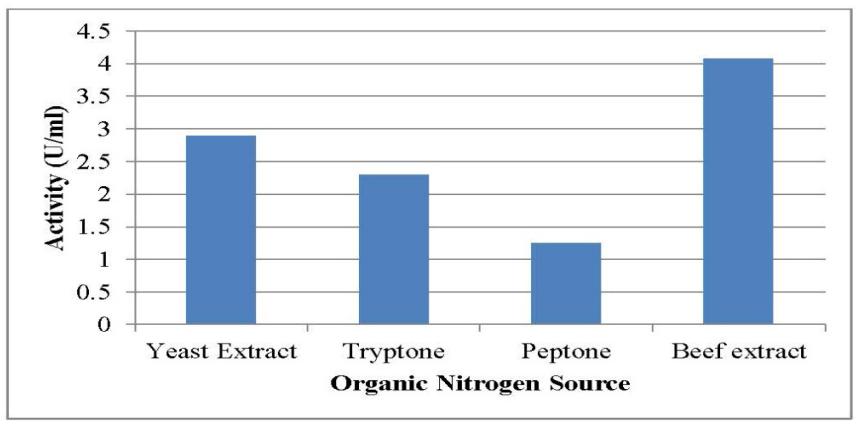

Figure 6: Effect of Organic Nitrogen Sources on Lipase Activity

Enhanced production of lipase was observed in presence of beef extract as organic nitrogen source and ammonium sulphate as inorganic nitrogen source in the media as per Figure 6 and 7 .

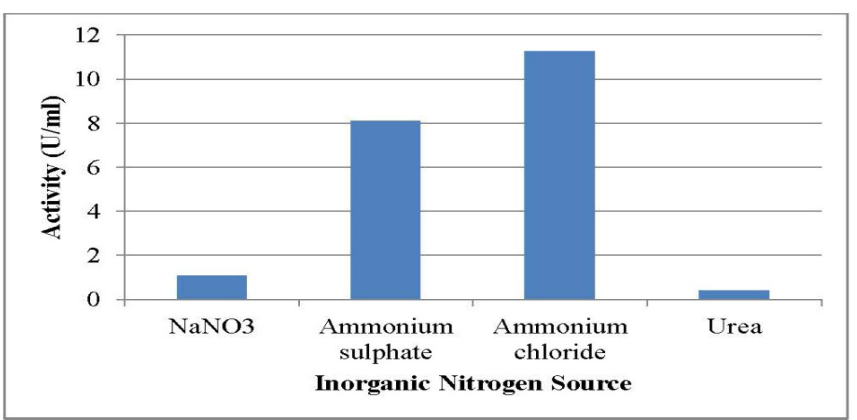

Figure 7: Effect of Different Inorganic Nitrogen Sources on Lipase Activity Effect of $p H$

Maximum growth and lipase activity of Lysinibacillus macroides FS1 was observed at $\mathrm{pH} 7$. As per Figure 8 
it was observed that at $\mathrm{pH} 5$ activity was maximum but growth was minimum and at $\mathrm{pH} 7$ growth and activity both are maximum.

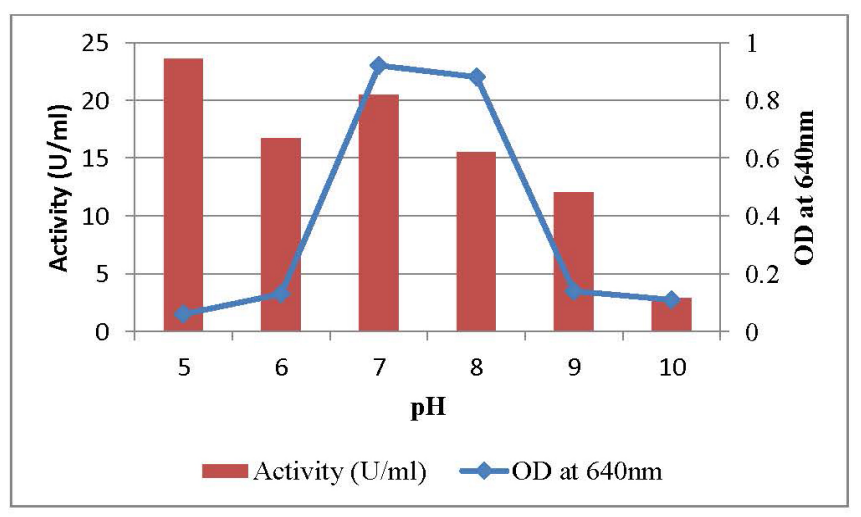

Figure 8: Effect of $\mathrm{pH}$

Lipase production was done in optimized media with optimized parameters and lipase assay shows that 5.4 fold enhanced production of lipase with activity of $16.75 \mathrm{U} / \mathrm{ml}$ by Lysinibacillus macroides FS 1 compared to its innate activity $(3.1 \mathrm{U} / \mathrm{ml})$ as shown in Figure 9.

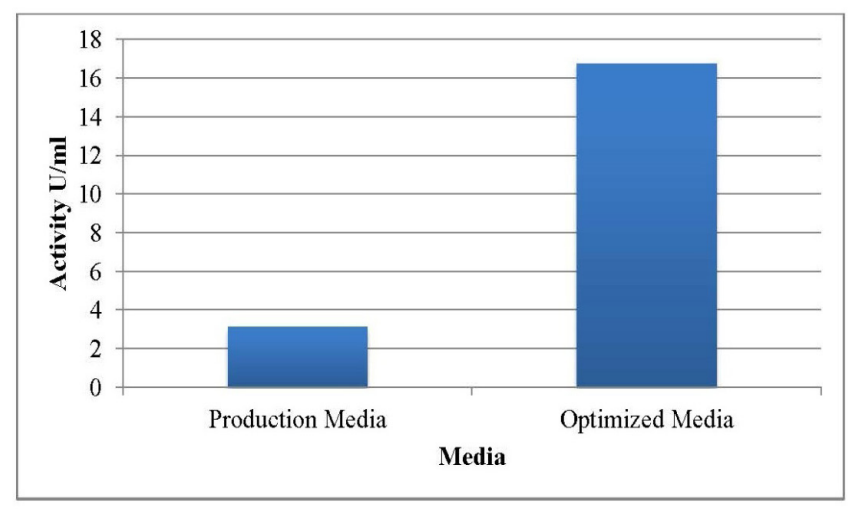

Figure 9: Lipase Activity In Production Media and Optimized Media

\section{Purification of Lipase}

Lipase was purified by ammonium sulphate precipitation. Most of the lipase was recovered at 30\% saturation. Partial purification of lipase from crude culture filtrate of Lysinibacillus macroides FS1 resulted in 15.28 fold purification with specific activity of $21.25 \mathrm{U} / \mathrm{mg}$ and $50.74 \%$ yield as per Table 3 .

Table 3: Partial Purification of Lipase From Lysinibacillus macroides FS1.

\begin{tabular}{|l|l|l|l|l|l|}
\hline $\begin{array}{l}\text { Purification } \\
\text { Steps }\end{array}$ & $\begin{array}{l}\text { Total Protein } \\
(\mathbf{m g})\end{array}$ & $\begin{array}{l}\text { Total Activity } \\
(\mathrm{U} / \mathbf{m})\end{array}$ & $\begin{array}{l}\text { Specific } \\
\text { Activity }(\mathrm{U} / \mathbf{m g})\end{array}$ & $\begin{array}{l}\text { Purification } \\
\text { Fold }\end{array}$ & $\begin{array}{l}\text { Yield } \\
(\%)\end{array}$ \\
\hline Crude lipase & 12 & 16.75 & 1.39 & 1 & 100 \\
\hline $\begin{array}{l}\text { Ammonium } \\
\text { sulphate }(30 \%)\end{array}$ & 0.4 & 8.5 & 21.25 & 15.28 & 50.74 \\
\hline
\end{tabular}

\section{Lipase Characterization}

\section{Protein Estimation by Lowrys method:}

Protein estimation of purified lipase was estimated by Lowry's method by using BSA as standard. Protein content of purified lipase was $0.4 \mathrm{mg} / \mathrm{ml}$.

\section{Stability to organic solvents}

The stability of produced lipase to organic solvents was tested and result reveals that lipase was stable in presence of methanol than ethanol. As per Table 4 it was noted that residual activity in presence of methanol and ethanol was $101 \%$ and $58 \%$ respectively, it indicates methanol has induces activity and ethanol inhibits the activity. Ethanol affects negatively on lipase activity. Hence methanol is most suitable acyl acceptor for transesterification reaction in which lipase from Lysinibacillus macroides FS1 were used as biocatalyst (Table 4).

Table 4: Stability of Purified Lipase from Lysinibacillus macroides FS1 to Alcohols.

\begin{tabular}{|l|l|l|}
\hline SI.No. & Test & Residual Activity in \% \\
\hline 1 & Control & 100 \\
\hline 2 & Methanol & 101 \\
\hline 3 & Ethanol & 58 \\
\hline
\end{tabular}

\section{Effect of temperature on lipase activity and stability}

The results shows that lipase was stable at $37^{\circ} \mathrm{C}$ and shows high activity at $37^{\circ} \mathrm{C}$ and lipase activity was reduced at $25^{\circ} \mathrm{C}$ and $45^{\circ} \mathrm{C}$ (Figure 10$)$.

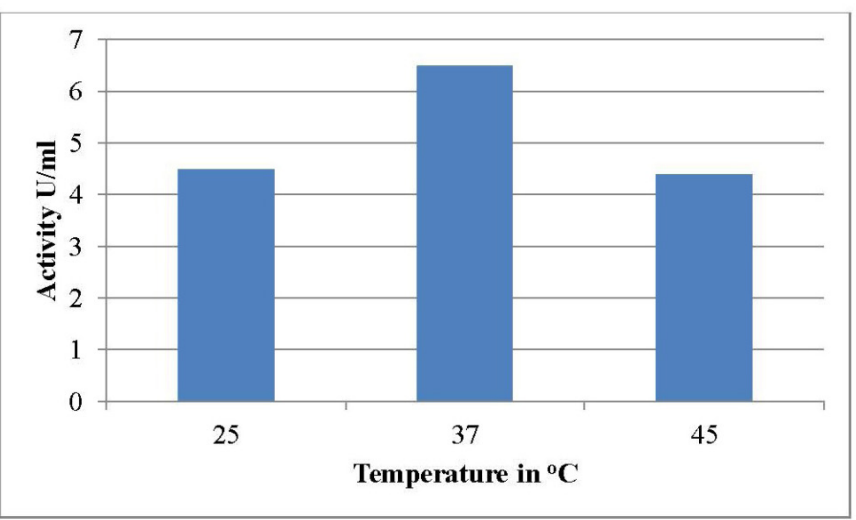

Figure 10: Stability of Purified Lipase From Lysinibacillus macroides FS1 t

\section{Discussion}

Lipases are potential group of hydrolyses and versatile biocatalyst catalyzing the hydrolysis of triacylglycerol there by having various industrial applications such as household detergent additive, textile industry, cosmetic industry, paper industry, pharma industry, synthesis of biopolymers, biodiesel industry, the production of enantiopure pharmaceuticals, agrochemicals, flavor compounds and pharmaceutical compounds synthesis etc $(3,4)$.Considering the importance of lipases at various industries, research needed to isolate lipase producing bacteria and its optimization for enhanced production. For isolation, oil rich soil sample were selected because of oily environment much suitable habitat for lipase producers as per Bharathi et al.(8) and Mobarak et al.(9).In the present study six different oil rich samples were selected which are not previously researched for 
the similar studies for isolation mentioned in Table 1. Many isolation studies reported was on TBA media as tributyrin agar is the selective media for isolation of lipase producing bacteria, similar isolation method was reported by Kiran et al.(21); Kumar et al. (22); Veerapagu et al.(23); Priyanka Patel et al.(20), Bharathi et al.(8) and E sirisha et al.(3).These samples were processed for the isolation and screening of lipase producing bacteria as discussed in material and methods as per Table $1 \& 2$. Among six bacterial strains from different sources, Lysinibacillus macroides FS1 were isolated from temple soil sample which shows maximum zone of clearance than other samples, which was from hanuman temple soil as per Table 2. As hanuman temple soil rich with oil because many devotees offering oil to lord and lighten the lamp in the temple so due to spillage of oil on soil makes the soil becomes oily that may facilitates the growth of lipase producers and that soil becomes prominent source as it is suitable habitat for lipase producing microorganisms as per reported by Toshi wadia et al, (24).

The isolate FS1 was found to be Gram positive rod. The colonial characters of isolate FS1 were large, irregular margin, cream color. Similar results were reported by Coorevits et al.(25) for Lysinibacillus macroides. The microbial identification and phylogenetic analysis of isolated strain was carried out using 16Sr DNA sequencing. 16SrDNA-based sequencing is the practical approach for bacterial identification(26). The results showed that strain had highest homology (98.46\%) with Lysinibacillus macroides LMG 18474 accession no (NR_114920.1). Figure 2 suggested that the isolate FS1 was close to Lysinibacillus macroides. Hence this strain was identified as Lysinibacillus macroides FS1(Figure 1).

As per reported by Kaya-Ongoto et al.(27) few studies have been shown that Lysinibacillus genera have possesses several enzymatic activities including lipolytic, proteolytic, cellulolytic, pectinolytic and amylolytic activities (16). Many lipase producing bacterial strains were isolated from diverse genera such as Bacillus (the most predominant), Pseudomonas, Serratia, Lysinibacillus, Cronobacter, Cellulosimicrobium (former Oerskovia) and Klebsiella sp, as per studies carried by Caterina Tomulescu et al. (28). Lysinibacillus among one of the genera which can be considered as lipase producer. In this study lipolytic activity of Lysinibacillus macroides FS1 were reported and can be considered as one of the potent lipase producer.Lysinibacillus is a spore forming bacteria which are highly resistant to physical and chemical influences and could be the reason of their survival in different contaminated environment such as oil polluted soil reported by Hassana et al. (29). The production media used in this study were similar to Bharathi et al. (8). The production of enzymes at industrial scale was performed in the submerged fermentation $(\mathrm{SmF})$ process, as this method of fermentation process easy to monitor and to control. SmF is more suitable for yeast and bacterial species as reported by .N. B.
Melani et al.(18). The use of submerged fermentation for lipase production using bacterial species gives satisfactory results studied by Vishwanatha T et al. (30). Therefore in this study production of lipase by isolated strain Lysinibacillus macroides FS1 were carried in submerged fermentation using lipase producing media as mentioned in methodology. Lipase activity of Lysinibacillus macroides FS1 were assayed by titrimetric method. Various methods of lipase assays are available, of these methods titrimrtric is simplest method similarly used by Priyanka Patel et al. (20) and Sirisha et al. (3). The innate lipase activity of Lysinibacillus macroides FS1 were reported as $3.1 \mathrm{U} / \mathrm{ml}$.

Lipase production was optimized to enhance the innate lipase activity. The way of making more effective lipase production process is modification in fermentation process and immobilization process for repeated reuse of enzymes. The most important stage in a biological process is optimization to improve efficiency and to develop cost effective process. (36). To enhance the lipase production Media components were optimized by single factor analysis as per Bharathi D et al. (8). The production of lipase from Lysinibacillus macroides FS1 was studied for the incubation period of 48-96 hr and it was observed that the lipase production from the Lysinibacillus macroides FS1 was found maximum $(3.1 \mathrm{U} / \mathrm{ml})$ at $48 \mathrm{hr}$. It is observed from the Figure 3 that lipase production was detected at $24 \mathrm{hr}$ and maximum production was achieved at $48 \mathrm{hr}$ of incubation and then decline. The results were similar to Veerapagu et al. (23) for Pseduomonas gessardii, the production decreased after $48 \mathrm{hr}$. This intimates that the lipase production by Lysinibacillus macroides FS1was occurred in a growth dependent fashion. Similarly reported in studies with Staphylococcus sp. Lp12 by Pogaku et al.(31).

The effect of $\mathrm{pH}$ on production of lipase was investigated by varying $\mathrm{pH}$ of media from 5-10. The isolate Lysinibacillus macroides FS1 shows maximum activity of $20.5 \mathrm{U} / \mathrm{ml}$ at $\mathrm{pH} 7$ (Figure 8). The results are in accordance with Prasad and Manjunath (32) who found similar results for the pseudomonas species at $\mathrm{pH}$ 7. As per Figure 8 the highest growth was observed at $\mathrm{pH} 7 \& 8$ and lipase secretion was highest at $\mathrm{pH} 5$ but very minimal growth was observed. It reveals that may be $\mathrm{pH} 5$ condition inhibits the growth but may influence the lipase secretion. Hence in this study $\mathrm{pH} 7$ was considered as optimum $\mathrm{pH}$ because of both growth and lipase production was maximum compared with other readings. As per studies carried by Coorevits et al.(25) with respect to Lysinibacillus macroides, $\mathrm{pH}$ 7.0-9.0 facilitates the growth, optimum growth occurring at $\mathrm{pH}$ 8.0, no growth occurs at $\mathrm{pH} 6.0$ hence similarly reported in this study as optimum $\mathrm{pH}$ of Lysinibacillus macroides FS1 was 7 as growth was maximum at this $\mathrm{pH}$. Lipase production can be enhanced by using some vegetable oils as these are inducers for lipase production and regarded as economically viable substrates for lipase 
production at an industrial scale. The amount of lipase secreted is related with the relative percentage of $\mathrm{C} 18$ : $\mathrm{n}$ fatty acid esters present in the respective oils. Among the various fatty acids accounted as an inducer for lipase secretion, oleic acid was observed to be preferred substrate for lipase production (19). Hence in this study oleic acid rich non edible oil instead of edible oil was used as inducer oil. Effect of different non edible inducer oil on lipase production was revealed that Honge oil was to induce higher lipase production than neem oil and palm oil as shown in Figure 4. Abul Kalam Mohammad Aminul Islam et al. (33) reported in his studies that honge oil comprises higher amount of unsaturated fatty acids $70 \%$ among that $51 \%$ oleic acid compared to other non edible oils. Hence honge oil can be used as a inducer oil to enhance the lipase production, it was reported first in this study. ( Data not available).

It was proposed that the lipase might be derived from carbohydrates in the medium with small quantities of lipid material as inducer. Hence various carbohydrates were tested at $3 \%$ concentration and the lipase activity was observed as shown in Figure 5. Among various carbon sources studied the maximum production of lipase was observed with galactose. Apparently, disaccharides were more promising than monosaccharides.(34) Galactose rated first $4.5 \mathrm{U} / \mathrm{ml}$ among others as best carbon source for Lysinibacillus macroides FS1 Similarly reported by S. Gaherwal et al.(35) for Bacillus sp. Similarly effective nitrogen sources for Lysinibacillus macroides FS1 was beef extract and ammonium chloride reported to be effective as shown in Figure 6 \& 7(15).

The production of lipase was enhanced to $16.75 \mathrm{U} /$ $\mathrm{ml}$ compared to innate activity of $3.1 \mathrm{U} / \mathrm{ml}$ there is 5.4 fold increase in lipase activity than innate activity at optimized conditions like $48 \mathrm{hr}$ of incubation time, $\mathrm{pH} 7$, Galactose as Carbon source, Ammonium sulphate and Beef extract as Nitrogen source and Honge oil as Inducer oil as shown in Figure 9.

The produced lipase was purified by $30 \%$ Ammonium sulphate precipitation since it was highly soluble in water, cheap and will not affect on structure of protein. Precipitation is the most practical technique, solubility of proteins were altered by adding salts and favor the formation of protein aggregates as per Melani N B et al.(18).The partially purified lipase had specific activity of $21.25 \mathrm{U} / \mathrm{mg}$. The recovery of lipase was $50.74 \%$ with purification fold of 15.28 as shown in Table 3 . The total protein content of lipase $0.4 \mathrm{mg} / \mathrm{ml}$ was determined by Lowry's method after purification.

Biodiesel production is one of the stunning applications of lipase. Lipase catalyzed biodiesel production was reported first by Mittelbach (2). The identification of the lipase producing organism which catalyse transesterification reactions is not easy. Few microbial lipases are currently available for biodiesel industrial purpose (10). Because may be one of the reason that the enzymes are inactivated or denatured in presence of organic solvents which are the co substrates in transesterification reactions thereby limiting their use in some cases. Therefore

solvent stable lipases are one of the leading biocatalysts in non-aqueous environment due to their unique property of catalysing a wide variety of useful transformations(17). The lipase from Lysinibacillus macroides FS1 demonstrated significant stability and activity in the presence of organic solvents which are used in transesterification reaction. As short chain alcohols may deactivate the lipase activity and as per the Table 4 it was noted that lipase from Lysinibacillus macroides FS1 was shown stability to methanol than ethanol so it can be used in transesterification reaction where it will be stable in presence of methanol and able to catalyse the tranesterification reaction for biodiesel production. Additionally, Lipase was tested for stability towards temperature and it was stable at $37^{\circ} \mathrm{C}$ (Figure 10) indicates transesterification process can be performed at $37^{\circ} \mathrm{C}$ therefore making the process cost effective.

\section{Conclusion}

From the present study it was concluded that temple soil has found to be potential source of industrially useful bacteria such as Lysinibacillus macroides FS1 which can be used as a potential bacterial source of lipase with methanol stability and pose to be a promising bacterial candidate for biodiesel industry as source of biocatalyst. The various factors like $\mathrm{pH}$, Inducer oil, and Carbon and Nitrogen sources were optimized. The maximum lipase production was obtained in medium containing $1 \%$ Honge oil as inducer, $3 \%$ Galactose as carbon source, 3\% Ammonium Chloride and 3\% Beef extract as nitrogen source, $\mathrm{pH} 7$ and $37^{\circ} \mathrm{C}$ temperature with agitation speed of $120 \mathrm{rpm}$. After optimization, lipase activity of Lysinibacillus macroides FS1 was increased by 5.4 fold. Partial purification of lipase from crude culture filtrate of Lysinibacillus macroides FS1 resulted in 15.28 fold purification with $50.74 \%$ yield. The results obtained indicate that Lysinibacillus macroides FS1 was potent lipase producer can be explored to higher scales of industrial level. Further scope of the work is to focus on purification process for maximum recovery and optimize biodiesel synthesis using lipase from Lysinibacillus macroides FS1.

Acknowledgment We thank Department of Biotechnology Basaveshwar Engineering College Bagalkot for providing facilities to carry out experiments.

\section{References}

1. Nawal, G., Irfan, M., Ashfaq, S. and Shakir, H.A. (2019). An overview of bacterial lipases and their enormous applications. Punjab Univ. J. Zool., 34(1): 61-71.

2. Yucel, S., Terzioglu, P. and Ozqmen, D. (2013). 
Lipase Applications in biodiesel Production. InTech Open.

3. Sirisha, E., Narasu, M. L. and Rajasekar, N. (2010). Isolation and optimization of lipase producing bacteria from oil contaminated soils. Advances in Biological Research, 4(5), 249-252.

4. Borkar,P.S., Bodade,R.G., Rao,S.R. and Khobragade,C.N.(2009).Purification and characterization of extracellular lipase from a new strain: Pseudomonas aeruginosa SRT 9. Brazilian. Journal of Microbiology,40(2):358-366.

5. Shimada, Y., Watanabe, Y., Sugihara, A., and Tominaga, Y. (2002). Enzymatic alcoholysis for biodiesel fuel production and application of the reaction to oil processing. Journal of Molecular Catalysis B Enzymatic, 17(3-5), 133-142.

6. Joshi, S. S. and Jobanputra, A. H. (2019). Isolation, Identification and Susceptibility Testing of Potential Lipase producing Bacterial and Fungal Strains from soil. Research Journal of Biotechnology, 14(8), 8996.

7. Saadatullah, Malook,I., Mehmood, J., Waheedullah., Muhammmad,N., and Zia ur Rehman. (2018). Isolation, identification and characterization of a lipase producing Pseudomonas.Journal of Biomaterials, 2(2),51-57.

8. Bharathi, D., Rajalakshmi, G. and Komathi, S. (2018). Optimization and production of lipase enzyme from bacterial strains isolated from petrol spilled soil. Journal of King Saud University - Science, 31(4), 898-901.

9. Mobarak-Qamsari, E., Kasra-Kermanshahi, R.and Moosavi-nejad, Z. (2011). Isolation and identification of a novel lipase producing bacterium, Pseudomonas aeruginosa KM110. Iranian Journal of Microbiology, 3(2), 92-98.

10. Chary, P. and Devi, Y. (2018). Isolation, Partial Purification and Characterization of Lipase Enzyme from Pseudomonas aeruginosa from Soil and Sewage Waste. Asian Journal of Biology, 6(2), 1-6.

11. Aktar, L., Khan, F. I., Islam, T., Mitra, S. and Saha, M. L. (2016). Isolation and characterization of indigenous lipase producing bacteria from lipid rich environment. Plant Tissue Culture and Biotechnology, 26(2), 243-253.

12. Femi-Ola, T. O., Odeyemi, A. T., Olaiya, B. S. And Ojo, O. O. (2018). Characterization of lipase from Bacillus subtilis isolated from oil contaminated soil. Journal of Applied and Environmental Microbiology, 6(1), 10-17.

13. Golani, M., Hajela, K. and Pandey, G. P. (2016). Screening, identification, characterization and production of bacterial lipase from oil spilled soil. International Journal of Current Microbiology and Applied Sciences, 5(3), 745-763.

14. Hasan, N. A., Nawahwi, M. Z., Yahya, N. and Othman, N. A. (2018). Identification and optimization of lipase producing bacteria from palm oil contaminated waste. Journal of Fundamental and Applied Sciences, 10(2S), 300-310.

15. Gupta, R., Gupta, N. and Rathi, P. (2004). Bacterial lipases: an overview of production, purification and biochemical properties. Applied Microbiology and Biotechnology, 64 (6), 763-781.

16. Kayath, A.C.,Vouidibio, M. A. Brice., Mokémiabeka, S. N., Kaya-Ongoto M. D., Nguimbi, E.(2020).The Genus Lysinibacillus: Versatile Phenotype and Promising Future. International Journal of Science and Research (IJSR), 8 (1),1238-1242.

17. Ryan, B., Priyanka, P., Kinsella, G. and Henehan, G. (2019). Isolation, purification and characterization of a novel solvent stable lipase from Pseudomonas reinekei. Protein Expression and Purification, 153, 121-130.

18. Melani, N. B., Tambourgi, E. B. and Silveira, E. (2019). Lipases: From production to applications. Separation and Purification Reviews, 49(2), 1-16.

19. Lakshmi, B. S., Kangueane, P., Abraham, B. And Pennathur, G. (1999). Effect of vegetable oils in the secretion of lipase from Candida rugosa (DSM 2031). Letters in Applied Microbiology, 29(1), 6670.

20. Patel, P. and Desai, B. (2018). Isolation, identification and production of lipase producing bacteria from oil contaminated soil. BMR Microbiology, 4(1), 1-7.

21. Kiran, G. S., Shanmughapriya, S., Jayalakshmi, J., Selvin, J., Gandhimathi, R., Sivaramakrishnan, S., Natarajaseenivasan, K. (2008). Optimization of extracellular psychrophilic alkaline lipase produced by marine Pseudomonas sp. (MSI057). Bioprocess and Biosystems Engineering, 31(5), 483-492.

22. Kumar, D., Kumar, L., Nagar, S., Raina, C., Parshad, R. and Gupta, V. K. (2012). Screening, isolation and production of lipase/esterase producing Bacillus sp. Strain DVL2 and its potential evaluation in esterification and resolution reactions. Archives of Applied Science Research, 4(4), 1763-1770.

23. Veerapagu, M., Shankar Narayan, A., Ponmurugan, K. and Jeya, K. R. ( 2013).Screening, Selection, Identification, Production and Optimization of Bacterial lipase from oil spilled soil. Asian J. Pharma Clin Res,6(3), 62-67.

24. Wadia, T. and Jain, S. K. (2017). Isolation, screening and identification of lipase producing fungi from oil contaminated soil of Shani Mandir Ujjain. 
International Journal of Current Microbiology and Applied Sciences, 6(7), 1872-1878.

25. Coorevits, A., Dinsdale, A.E., Heyrman, J., Schumann, P., Van Landschoot, A., Logan, N.A. and De Vos, P. ( 2012).Lysinibacillus macroides sp. nov., nom. rev. Int. J. Syst. Evol. Microbiol, (62),11211127.

26. Lee Pin, Li., Karbul, H. M., Citartan, M., Subash, C. B. G., Thangavel, L. and Thean-Hock Tang. (2015). Lipase-Secreting Bacillus Species in an OilContaminated Habitat: Promising Strains to Alleviate Oil Pollution. BioMed Research International,1-9.

27. Kaya-Ongoto, M. D., Kayath, C. A., Mbozo, A. B. V., Mitoko, G. M., Wilson, S. P. E., Kinavouidi, D. J. K. and Nguimbi, E. (2020). Prime Enzymatic Exocellular Background of Lysinibacillus louembei. Advances in Microbiology, 10, 95-109.

28. Tomulescu, C., Moscovici, Misu, Ghiorghita, A., Petrescu, M., Vladu, M., Tamaian, Radu, \& Vamanu, A. (2015). Microbial screening for lipase and amylase production using newly isolated strains from various biotopes. Scientific Bulletin Series F Biotechnologies, XIX, 271-280.

29. Hassana, A., Vincent, B. T., Ushuji, O. D., Yakubu, N., Boko, U. H. and Gogo, M. F. (2019). Molecular identification of hydrocarbon degrading bacteria isolated from contaminated soil of automobile mechanic workshop in lapai, Niger State. International Journal of Pure and Applied Bioscience, 7(4), 31-37.

30. Vishwanatha, T., Sharangouda. J. P., Siddalingeshwar, K.G. and Lingayya H.(2019). Isolation and Screening of Lipase Producing Microbes from Oil Contaminated Soil. Advances in Bioplastics,7-13.

31. Pogaku, P., Suresh, A., Srinivas, P. and Ram Reddy, S. (2010).Optimization of lipase production by Staphylococcus $s p$. Lp12. African Journal of Biotechnology, 9(6),882-886.

32. Parsad, M. P. and Manjunath, K. (2012). Effect of media and process parameters in the enhancement of extracellular lipase production by bacterial isolates from industrial effluents. International Journal of Microbiology Research, 4(8), 308-311.

33. Islam, AKMA., Primandari, SRP. and Yaakob, Z. (2018). Non-Edible Vegetable Oils as Renewable Resources for Biodiesel Production: South-East Asia Perspective Advances in Biofuels and Bioenergy, IntechOpen.

34. Rani, C. and Panneerselvam, A. (2009). Influence of environmental and nutritional parameters on lipase production. ARPN Journal of Agricultural and
Biological Science, 4(5, September), 39-43.

35. Gaherwal, S., Lal, A., Chourasia, P. and Wast, N. (2015).Studies on lipase producing bacterial strains isolated from different soil. Academic Journal of Plant Sciences, 7(1), 01-05.

36. Zavarise, J. P., Pinotti, L. M. and Freitas, R. R. (2019). Progress in the production of fungal lipases by submerged fermentation. International Journal of Advanced Engineering Research and Science, 6(12), 367-373.

37. Aderiye, B. and Sulaimon, A. (2017). Optimization and lipase production of Lysinibacillus sphaericus in domestic oil rich waste water. Biotechnology Journal International, 19(4), 1-12.

38. Alhamdani, M. A. and Jabbar Alkabbi, H. J. (2016). Isolation and identification of lipase producing bacteria from oil-contaminated soil. Journal of Biology, Agriculture and Healthcare, 6(20), 22243208.

39. Fakorede, C.N., Itakorode, B.O., Olayiwola, A.T. and Anifowose, T.E.(2019).Lipase Producing Potential of Different Bacteria Species Isolated from Cooking Oil Contaminated Soils. International Journal of Environment, Agriculture and Biotechnology (IJEAB),4(2),314-320.

40. Kaur, B., Taggar, M. S., Sharma, P. and Kaur, P. (2017). Screening of bacterial strains for lipase production and its application in biodiesel synthesis. International Journal of Chemical Studies, 5(3), 230-236.

41. Kumar, A., Parihar,S. and Batra. N. (2013). Enrichment, Isolation and Optimization of LipaseProducing Staphylococcus Sp. From Oil Mill Waste (Oil Cake).Journal of Experimental Sciences, 3(8),26-30.

42. Bhavani,M., Chowdhary, G.V., David,M. and Archana, G. (2012).Screening, isolation and biochemical characterization of novel lipase producing bacteria from soil samples. International Journal of Biological Engineering,2(2), 18-22.

43. Mukhtar, H., Hanif, M., Rehman, A. U., Nawaz, A. and Haq, I. U. (2015). Studies on the lipase production by Aspergillus niger through solid state fermentation. Pakistan Journal of Botany, 47, 351354.

44. Patel, M., Mistry, J., Desai, S., Patel, S. and Desai, S. (2016). Isolation and Characterization of Lipase producing Bacteria from Vegetable Oil Spillage Site. International Journal of Current Microbiology and Applied Sciences, 5(8), 214-232.

45. Patel,U., Chandpura, J., Chauhan, K. and Gupte, S.(2018). Screening and Isolation of an Organic 
Solvent Tolerant Lipase Producing Bacteria from Various Oil Contaminated Sites. Indian Journal of Applied Microbiology, 21 (1), 22-36.

46. Priyanka, P., Kinsella, G., Henehan, G. T. and Ryan, B. J. (2019). Isolation, purification and characterization of a novel solvent stable lipase from Pseudomonas reinekei. Protein Expression and Purification, 153, 121-130.

47. Ranganathan, S. V., Narasimhan, S. L. and Muthukumar, K. (2008). An overview of enzymatic production of biodiesel. Bioresource Technology, 99(10), 3975-3981.
48. Sharma, R., Chisti, Y. and Banerjee, U.C. (2001). Production, purification, characterization and applications of lipases. Biotechnology Advances, 19 (8), 627-662.

49. Tripathi, R., Singh, J., Bharti, R. K. and Thakur, I. S. (2014). Isolation, purification and characterizartion of lipase from Microbacterium sp. and its application in biodiesel production. Energy Procedia, 54, 518529.

50. Mohan, T. S., Palavesam, A. and Immanvel, G. (2008). Isolation and characterization of lipase producing Bacillus strains from oil mill waste. African Journal of Biotechnology, 7(15), 2728-2735. 